\title{
Microgram per Specimen
}

National Cancer Institute

\section{Source}

National Cancer Institute. Microgram per Specimen. NCI Thesaurus. Code C67358.

A derived unit expressed as quantity in micrograms per specimen. 